\title{
CALL in Asia During Covid-19 and Models of E-Learning
}

\author{
Vu Phi Ho Pham ${ }^{*}$, Thao Nguyen Da Vo
}

\author{
${ }^{1}$ Faculty of Foreign Languages, Van Lang University \\ ${ }^{2} \mathrm{VN}$-UK Institute for Research and Executive Education \\ *Corresponding author's email: ho.pvp@vlu.edu.vn
}

\begin{abstract}
Corona Virus' pandemic (Covid-19) has affected all of the world's aspects, such as economics, lifestyles, culture, education, etc. Most schools and universities have been shut down for the safety of students. Then e-learning has been employed in many schools and universities to keep education going on. However, many lecturers/teachers and students in Vietnam have not been familiar with this teaching/learning mode yet. Training lecturers/teachers to use the elearning system at a school or university is an important issue in terms of effective teaching/learning and school management. Few research studies have been investigated to study the useful model of e-learning classrooms during this critical time. This paper presents an overlook of e-learning issues around Asia during the Corona Virus pandemic. It then examined a case study on e-learning at a university in Vietnam during the lockdown situation. The study revealed that the implementation of e-learning in Vietnam still had many obstacles in terms of Internet connection, available devices, economic conditions, and the students' unwilling-perceptions. The study also provided a model of e-learning for the school/university management and the lecturers/teachers who wish to run their e-learning classes effectively.
\end{abstract}

Keywords: Corona Virus' pandemic, Covid-19, e-learning, online-meeting, LMS, pre-recording video, video clips.

\section{ISSUES OF E-LEARNING IN ASIA}

Since Corona Virus (Covid-19) has been outspread worldwide, all aspects of economics have been badly affected, and education is not an exception. In Asia, over 1.5 billion university students in 185 countries have been lockdown due to Coronavirus (COVID-19) pandemic (Pham \& Ho, 2020 [1]; Jamal, 2020 [2]; Dharmaraj, 2020 [3]). When the students stay at home, schools, colleges, and universities need to keep on going with the training processes by applying distance studies from institutions to homes. Many higher education institutions in most countries, including East Asia and Southeast Asia, are transmitting to online learning (Jamal, 2020 [2]; Rahman, 2020 [4]; Yarrow, 2020 [5]; Hayashi, et al., 2020 [6]). Besides, two-thirds of these universities' universities report that they need to switch from classroom teaching and learn to elearning. However, the COVID-19 pandemic would probably alter the direction of our thought on how the sector can and should work [1]. The pandemic of the coronavirus (COVID-19) is rapidly evolving innovation and looking for alternatives to Online learning at many universities in most countries, especially East Asia and Southeast Asia (Jamal, 2020 [2]; Rahman, 2020 [4]; Yarrow, 2020 [5]; Hayashi, et al., 2020 [6]). Dhawan (2020) asserted that the Corona Virus epidemic is an opportunity to make the best out of the present situation [2]. There are many options available in this challenging situation, and teachers are required to choose the right method and use it to educate their students.

Online education is defined as learning experience using various devices including smartphones, iPads, desktops, laptops and internet access in synchronous or asynchronous environments. The synchronous learning environment is structured in the sense that students take part in live lectures, that educators and learners are communicating in real-time and that immediate feedback is possible. Asynchronous learning environments, by contrast, are not properly organized [2]. In Dhawan, the online learning mode is very easily available and reaches remote and rural areas as well. The way of education is considered comparatively cheaper in relation to lower costs of 
transport, housing and institutional learning. Flexibility is another interesting aspect of online learning; a student may plan or prepare online classes. Combining face-to-face lectures with technology results in mixed learning and reversed lessons, improving students' learning skills. All over the world, students will learn, thereby creating new skills that lead to lifelong education. The Government recognizes the increasing importance of online learning in this competitive environment too [2].

In Vietnam, before the Corona Virus pandemic outbreak, e-learning was on the edge of higher education (Pham \& Ho, 2020 [1]) and received fewer respects from society. However, During the Covid-19, 110 out of 240 Universities in Vietnam have employed e-learning, and $70 \%$ of them are of private universities (MOET, 2020 [9]). VNPT E-Learning experienced a four times rise to 5 million, with a high of 100,000 hourly visitors. In the same way, Viettel Study got 41 million visits per month. It has been implemented in nearly 26,000 schools globally, with a database of 29,000 lessons at all stages [3].

In Malaysia, this equates to 4.9 million school students and 1.2 million students at higher education institutions, which include some 130,000 international students, including public and private, polytechnic, and community universities [4]. In the Republic of Korea, the Ministry of Education estimated that 3 million users will concurrently access each of the two public online learning sites (i.e., KERIS e-Learning Site and EBS Online Class) (i.e., KERIS e-Learning Site and EBS Online Class). It extended the infrastructure accordingly to provide reliable education service [5].

Countries with existing good internet infrastructures, such as South Korea, Japan, Taiwan, and Singapore, have significant advantages when they implement online educational activities. In South Korea, the Education Ministry expected that during this era 3 million users will have access to two online public learning platforms. Teachers use public and private online training resources to take real-time lessons and to provide students with teaching material and assignments (MOE, 2020 [10]). During the Corona Virus pandemic in Japan, some sites provide free access to basic services. It was commonly used by university students (MOE, 2020 [10]). During the pandemic until 17 August 2020, all internet service providers in Sri Lanka have free access to university web servers. More than $90 \%$ of universities and colleges conduct e-learning (Hayashi et al., 2020 [6]). According to Yarrow (2020) [5], prepared programs, students, and teachers' adaption to online learning is a big issue. Getting the infrastructure in place makes it much easier to switch to online teaching and learning. According to Hayashi, et al. (2020) [6], Higher education institutions in Sri Lanka have used existing web server Moodle-based learning management systems. Zoom can be periodically tracked by the network.
In Vietnam, the service providers of VNPT, FPT, and Viettel also run the online platforms for e-learning for schools free of charge during the pandemic of COVID19. Most schools let the teachers choose the adequate type of online classes and platforms to offer online courses and/or one-way classrooms (MEO, 2020 [10]). According to Jamal (2020) [2], Southeast Asian countries have remarkable growth in internet access and mobile phone use over the last few years as seen as the world's most devoted internet users. There are at least 360 million internet users in Southeast Asia, and about 90 percent of them link to the Internet, primarily through their mobile devices. This is a tremendous accomplishment compared to many other nations, and the increase in the use of the Internet and mobile devices is already an advantage during the pandemic.

\subsection{Problem statements}

Using technology is really a challenge for many Asian teachers (Ta, 2020) [11], and problems of teachers and students' perceptions on e-learning (Yarrow, 2020) [5]. Many teachers and lecturers are not friendly with technology or e-learning yet. Most of the teaching activities today are still in the mode of traditional methods. According to Dhawan (2020) [8], educational institutions are currently focused only on conventional learning methods in India. They follow the traditional set up in a classroom with face-to-face lectures. In Malaysia, Rahman (2020) [4] reported that some lecturers were not keen to even on enrolling in the learning management system. In China, many Chinese teachers have only begun to learn skills such as speaking spontaneously in front of a camera, using a digital red pen during PowerPoint presentations, and engaging students through online written comments (Carey, 2020 [12]; Ta, 2020 [11]).

Like other countries, in Sri Lanka, many faculty staff were not used to online teaching in higher education institutions (Hayashi, et al., 2020 [6]). They always had problems with technical issues when they started to implement e-learning. In Korea, both students and teachers lacked the technical skills to interact effectively in online class environments. Both students and professors said that they were not trained to do it (Kalenzi, Back, \& Yim, 2020 [13]).

In terms of students' views, Indonesian students reported that they find it hard to stay focused. They believe that online lectures are less successful and struggle to connect online with lecturers and peers (Yarrow, 2020 [5]). Yet, in China, many students were dealing with a lack of resources at home, such as computers and high-speed Internet, mostly from lowincome families (Ho-him, 2020 [14]). In Korea, the students rated low satisfaction regarding their online learning and their dissatisfaction with tuition fees. $50 \%$ of the students considered taking a leave of absence in the subsequent semester (Kalenzi, Back, \& Yim, 2020 [13]). Many students were against the e-learning 
activities in Vietnam and claimed that they paid tuition for face-to-face classrooms, not for e-learning.

Regarding e-learning teaching activities, many teachers conducted their e-learning classes in such a way that they recorded a lecture and posted it online for students to access and view (Carey, 2020 [12]). According to Hayashi et al. (2020) [6], in middleincome countries, 54 percent of the e-learning classes were given video lectures, and 40 percent were evaluated online. In Sri Lanka, $40 \%$ of the teachers used PowerPoint presentations, online quizzes, and online whiteboards for the online classes (Hayashi et al., 2020 [6]). The review of the British Council for China, Hongkong, Malaysia, and Vietnam indicated three gaps when applied e-learning (Ta, 2020 [11]): (1) Lack of comprehensive framework; (2) Lack of expertise and skills in teaching online; and (3) Students' lack of self-studies.

Due to the above-stated problems, the questions were raised to educators and school leaders. What does the e-learning framework look like? Is it just a Powerpointrecorded presentation? Is it just an online meeting to learn the content of the lesson? How to cover the content of the lesson on e-learning? And how does the university manage the teaching/learning activities?

\subsection{Rearch gaps}

The current study found some gaps in the implementation of e-learning around Asian institutions. First, E-learning is not just simply giving the teachers an LMS platform, MS TEAM, a Zoom account, Google Meet, Cisco Webex, or BigBlueButton to have a lesson on it. Second, the teachers need to know what to include in the lessons, what to instruct the students, and how to cover all their lessons' core content. Finally, How to help the teachers shape their e-learning skills is an essential issue to be further explored

\section{METHODOLOGY}

This study employed a descriptive research design to explore data from the students at a university in Vietnam during the school lockdown because of Corona Virus's pandemic (Covid-19). All the university lecturers were "forced" to use an e-learning system during Corona Virus's pandemic. The second semester of the Academic year 2019-2020 took place with face-to-face classrooms for two weeks before the pandemic of Covid-19. As the universities and schools around the country were lockdowns, all the lecturers worked to start-up e-learning though it was frustrating (for the lecturers)

\subsection{E-learning/teaching framework}

As the e-learning (online-teaching) was running to all teaching and learning activities via LMS Moodle and MS-TEAM (Microsoft 365), the university leaders needed to train the teachers and students to get used to the e-learning system. The lecturers were also introduced to use Loom (loom.com) and Zoom to record Video clips for the teaching lessons (See fig. 1).

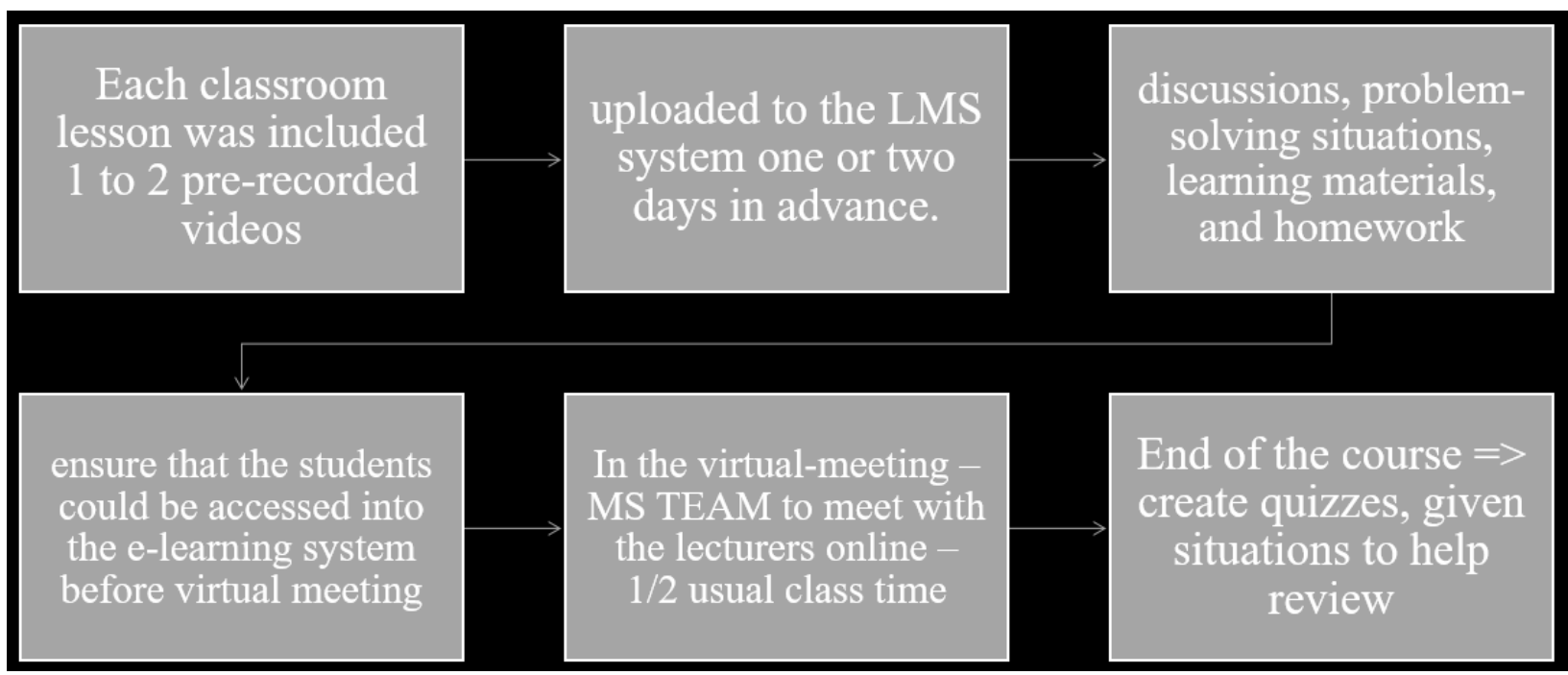

Fig. 1 Teaching activities for e-learning

Each classroom lesson was included 1 to 2 prerecorded videos relating to the lesson's core content, then uploaded to the LMS system one or two days in advance (before the online meeting) for the students to learn online. Besides, the lecturers design some activities for the students, such as discussions in the forum, exercises, problem-solving situations, learning materials, and homework. This was done to ensure that the students could be accessed into the elearning system and conduct their studies any time before meeting with the lecturers virtually.

In the virtual-meeting classrooms, the students and lecturers used their professional emails to sign-in the MS-TEAM of Office 365 to meet with the lecturers 
online. During this virtual meeting, the lecturers would deal with all the students' questions relating their what they had learned from the video clips, learning materials, problem-solving, exercises, and homework from the LSM system (Moodle). The lecturers instructed or gave the students some guidelines to complete the strenuous activities or solve them. Also, if the students failed to understand all the lessons' points, the lecturers would provide them with explanations or examples to help them cope with it. During the virtual meeting, the lecturers recorded what occurred in the meeting and posted the LMS system's link to revisit the e-learning website to review their lessons. This was also helpful for those students who missed the virtual classes. Fig. 2 presents the teaching model for e-learning.

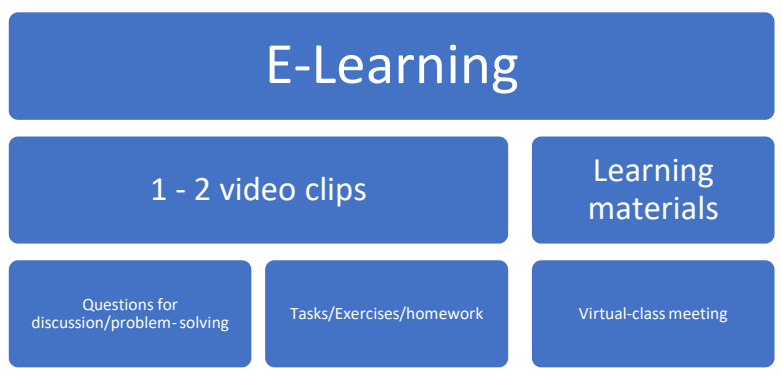

Fig. 2 The teaching framework for e-learning

At the end of the course of e-learning, the lecturers employed the feature of Quizzes in the LMS (Moodle) to create quizzes to help the students review the contents they had learned. Exercises and situations for problem-solving were also employed to review all the main content of the course. Some online-meetings via MS TEAM were used to help students solve complicated learning issues.

\subsection{Survey questionnaire}

The survey questionnaire was sent to all students at a University and received 1567 responses. The questionnaire was set-up with the Form of Office 365. Only the university's emails to the students could be accessed and complete the survey. The questionnaire survey was sent to the students to respond in one month, from 12 July to 12 August 2020.

They came from the faculty of Economics, Law, Tourism, Foreign Languages, Computer Science, Mechanics, and Technology. Of which $35 \%$ of the students $(\mathrm{n}=553)$ were Freshmen, $29 \%$ were Sophomore $(n=452), 25 \%$ were Juniors $(n=387)$, and $11 \%$ of them $(n=175)$ were Seniors.

\section{FINDINGS}

The total samples who responded to the questionnaire survey were 1567 students. Among these respondents, 96\% $(n=1482)$ had experienced E-learning during the Lockdown period of Corona Virus (Covid-19), while 4\% had no experience with the e-learning system yet. Of $96 \%$ of the students ( $\mathrm{n}$ $=1509), 318$ students $(21 \%)$ had the experience of learning e-learning from 1 to 2 courses, 410 students (27\%) had experience to learn from 3 to 4 classes with e-learning, and 781 students $(52 \%)$ took five or more than five courses with e-learning. The reasons for $4 \%$ of the students $(n=53)$ not attending the university's e-learning system reported in the qualitative data were as follows. First, some students were not affordable for the e-learning system. they did not have enough conditions to study with the elearning system for technical devices such as smartphones, laptops, iPad, or desktop computers. "Mỗi lần học online thì e phải ra quán net để có thể học nhưng từ lúc các quán net đã đóng hết và e không còn cách nào để có thể học tiếp được". Second, they were unwilling to study with e-learning for paying for traditional study mode, not e-learning mode. "Em đóng tiền vào là để học offline chứ không phải học online". Third, some of them were busy with their job/part-time jobs. "Em đi làm thêm không có thời gian và laptop". Finally, some felt uncomfortable to have their studies with a small smartphone. "Học không hiệu quả. Học trực tiếp trên trường còn chưa tiếp thu xong nói gì là học trc cái điện thoại”. Figure 3 presents the employment of digital devices that the students used for e-learning.

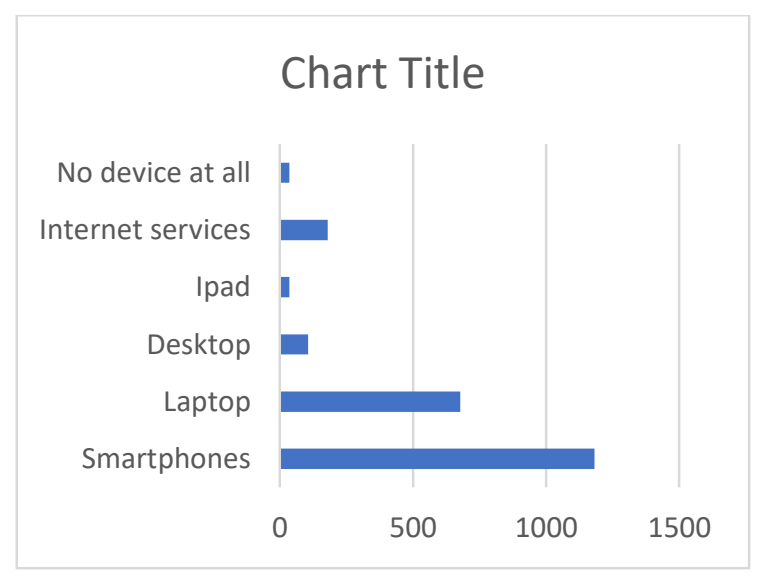

Fig. 3 Students' uses of digital devices for elearning

Fig. 3 presents the digital devices that the students employed to do their e-learning in their own space. Smartphones were seen as the most favored device used for their convenience $(n=1182 ; 75 \%)$. Many students today equipped themselves with smartphones, and they were easy to access the Internet. LMS (Moodle) and MS TEAM of Office 365 also had Apps on the smartphone via Google Play. So the students were able to download them to 
their mobile devices to do their studies. Laptops/Notebooks were the second most affordable devices that the students used to conduct their elearning $(\mathrm{n}=678 ; 43 \%)$. The students did not popularly use desktops and Ipad because many of them left far from their homes when they pursued their studies at universities. Of 1567 respondents, 180 students $(11 \%)$ did not have any devices to do their e-learning, so they had to use the Internet services nearby their locations. Hayashi et al. (2020) study showed that students had smartphones, but access to video camera laptops and desktops was inadequate. Whereas approximately 90 percent of

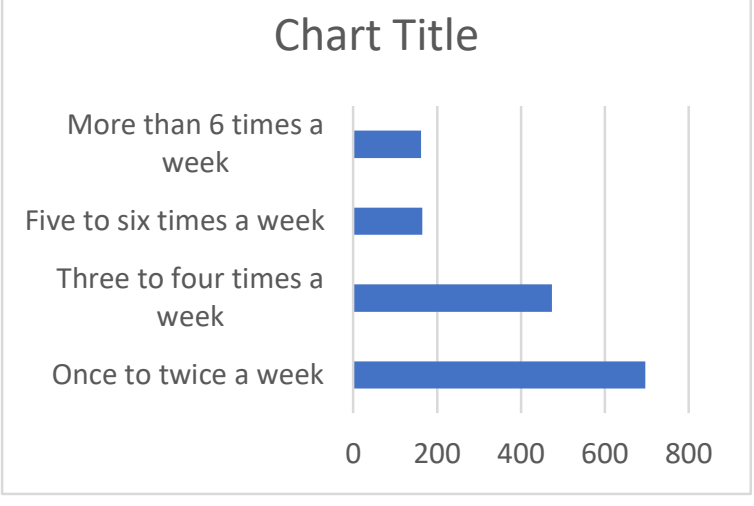

Fig. 4 Frequency of visiting the LMS to study

Figure 4 illustrates the frequencies of students who visited the LMS (Moodle) to conduct their studies online. As can be seen, the most frequent was that most of the students visited the LMS once or twice a week to study online. Many other students visited the LMS three or four times a week to do their studies. This indicates that many students conducted their autonomous learning during the Covid-19 pandemic when they did not physically come to the classrooms. In Sri Lanka, more than 55\% of students who responded online joined daily, while approximately $10 \%$ said they engaged once a week in online learning (Hayashi et al., 2020 [6]).

As shown in Figure 5, most of the students spent from 31 to 59 minutes conducting their self-study online. Very few students spent from 1.5 to 2 hours to stay online for listening to the video lectures or doing exercises. This indicates that students could not focus too long on learning the new knowledge. This finding contributed to the suggested model for e-learning of the current study. Fig. 6 presented the preferred activities when they conducted their autonomous learning. students reported possessing smartphones, only 55 percent of state students and 66 percent of NGOs said they owned a portable computer. Just $7 \%$ of state students and $12 \%$ of non-state students announced that they had a laptop. For a number of students, smartphones were not conducive to reading all materials and completing written assignments and quizzes using the learning management method. Fig. 4 presents the frequency of times students visited the LSM to do their self-studies, and Fig. 5 presents the length of time when the students conducted their autonomous learning.

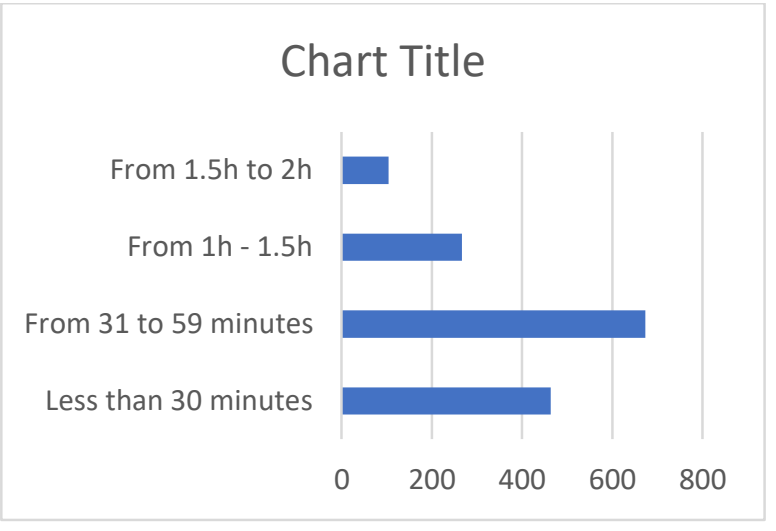

Fig. 5. Times spending on the LMS for studies

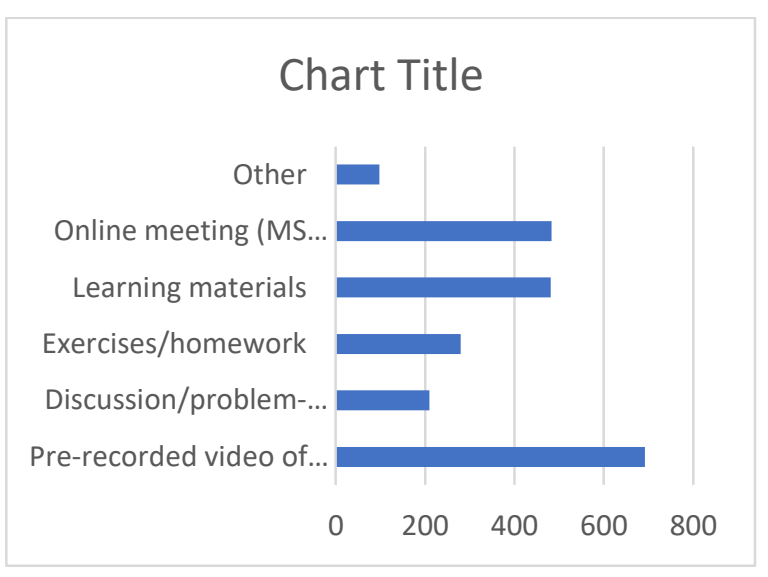

Fig. 6 Students' preferences of activities and resources

Fig. 6 illustrates the students' preferences of learning activities and resources when they conducted their autonomous studies via the LSM (Moodle). First, the most favorite recourses that the students preferred to learn new knowledge via LMS was the lectures' pre-recorded video. The second favored resource that the students preferred to do their autonomous learning via the LMS system was the record of online-meeting via MS TEAM that the lecturer implemented their teaching activities synchronously. In this online teaching activity, the lecturer met with their students as a normally scheduled calendar to meet with the students, respond to their questions, and solve problems if they did not understand or do them independently. 
The third most favored resource that the students wish to have for their autonomous learning via the LMS was the learning materials. In the current study, the learning materials refer to the book chapters relating to the content of the lesson, the outof-the book sources that the lecturers provided to their students for references, or sometimes the video clips relating to their content of the lesson that the lecturers made use from the Youtube and embed to the LSM system for the students to learn. The less favored activities that the students did not prefer much were problem-solving, exercises, discussion, or homework. These activities were not a passive resource that the students received. They required the students to involve in critical thinking, solving problems, or present their stances on some points that they agreed or disagreed with. It requested the students to actively participate in the learning process rather than become passive receivers of knowledge.

Regarding this issue, in the quantitative data, many students stated "no more e-learning" because it caused them a lot of frustration. However, some students suggested some more activities for the elearning to be more effective, such as Games, Quizzes (Cuối mỗi buổi học cần có câu hỏi trắc nghiệm để cũng cố kiến thức xem sinh viên tiếp thu được bao nhiêu). Some students suggested more references and more examples to illustrate the lessons (Em muốn giảng viên có thêm ví dụ minh họa thực tiến nhiều để có thể tiếp thu kiến thức dễ hiểu hơn). For some hands-on practice classes, the students suggested including videos for tasksolving so that they could learn how to solve the problems of hands-on practices easily (Em cần video giải các ví dụ). Significantly, many students suggested that there be more interactions between teacher-students student-student (Giao tiếp và trao đổi với sinh viên nhiều hơn, ... Kết nối với sinh viên).

In terms of each video clip's length, the students suggested that Long video clips seemed not to be interesting to the students to watch and learn. It should be shorter in length. (Giảng viên nên rút ngắn bài giảng thay vì kéo dài khiến sinh viên nhàm chán không nhớ nổi bài hay không hiểu mình đang học cái gì). Many lecturers wished to tell students everything relating to the lesson. This was the lecturers' good intention, but somehow it took the video clips too long to complete a section. Normally it took one hour or more in the current situation. Therefore, the study suggested that the pre-recorded video clips' length should be between 15 to 20 minutes and separated the lesson into 2 or 3 video clips. Each clip should include a complete section of the lesson's main content. The students could then arrange their time to watch and learn at a convenient time during the week.

Table 1.

Students' evaluation of the activities \& resources via E-learning

\begin{tabular}{|c|c|c|c|c|c|}
\hline \multirow[b]{2}{*}{ No. } & \multirow[t]{2}{*}{ Students' Evaluation } & \multicolumn{2}{|c|}{ Not effective enough } & \multicolumn{2}{|c|}{ Effective enough } \\
\hline & & $\mathrm{n}$ & $\%$ & $\mathrm{n}$ & $\%$ \\
\hline 1 & Evaluation of the pre-recorded video lectures & 371 & $25 \%$ & 1098 & $75 \%$ \\
\hline 2 & $\begin{array}{l}\text { Assessment of the given exercises, homework, or } \\
\text { problem-solving }\end{array}$ & 540 & $37 \%$ & 917 & $63 \%$ \\
\hline 3 & Assessment of the shared discussion forum & 612 & $42 \%$ & 847 & $58 \%$ \\
\hline 4 & $\begin{array}{l}\text { Evaluation of all the activities on the LMS that } \\
\text { cover the content of the course }\end{array}$ & 625 & $43 \%$ & 826 & $57 \%$ \\
\hline 5 & $\begin{array}{l}\text { Assessment of the quizzes that the teachers used to } \\
\text { review the lessons }\end{array}$ & 482 & $34 \%$ & 947 & $66 \%$ \\
\hline 6 & Evaluation of the effectiveness of E-learning & 420 & $29 \%$ & 1035 & $71 \%$ \\
\hline
\end{tabular}

Table 1 presents the students' evaluation of the activities and resources provided on the LSM for the students to conduct their autonomous learning via the LMS. $75 \%$ of the students $(n=1098)$ confirmed that the pre-recorded video lectures were effective for learning the new knowledge via LMS. When watching the video clips, the students could learn the new lesson's main content when they do their autonomous learning. Also, learning through the pre-recorded video clips, the students could watch and pause to listen again and again to master new knowledge. To review what they had learned, quizzes were also highly valued by the students to consolidate the knowledge before taking the tests. The students also favored problem-solving, exercises, or homework as activities to help them cover the lessons' main content. 
Table 2.

Students' frequencies of online meetings via MS TEAM

\begin{tabular}{lrr}
\hline Frequencies & n & \% \\
\hline Always & 206 & $13 \%$ \\
Usually & 926 & $60 \%$ \\
Sometimes & 341 & $22 \%$ \\
Never & 64 & $4 \%$ \\
\hline Total & 1537 & $100 \%$
\end{tabular}

As illustrated in Table 2, among 1537 responses, $73 \%$ of the students $(n=1132)$ regularly participated in the Online-meeting via MS TEAM of Office 365. $22 \%$ of them $(n=341)$ stated that they sometimes took part in those classes, while $4 \%(n=64)$ confessed that they never do it. In the qualitative data, these irregular online-meeting students claimed that they did not participate in the onlinemeeting due to the reasons of (1) poor Internet connection (Mạng không tốt, thường xuyên bị văng và không vào được), (2) the Internet $\mathrm{App}$ of TEAM on a smartphone was not running well, (3) they had to work part-time to overcome the demanding Table 3. situations because of economic crisis (vì thời gian này nhà đang khó khăn về kinh tế phải đi làm hồ mưu sinh nên em không có thời gian để lướt web nhiều), (4) and some of them revealed that they did not have any devices to take these kinds of class meetings (Mỗi lần học online thì e phải ra quán net để có thể học nhưng từ lúc các quán net đã đóng hết và e không còn cách nào để có thể học tiếp được). Most of all, (5) they stated that they felt not practical to take classes online in such a way compared to face-to-face learning (Bởi vì em thấy học rất khó tiếp thu lắm ạ, em muốn học trực tiếp trên lớp để tiếp cận hơn vối giảng viên và cũng dễ trao đổi hơn trong lúc học ạ).

The same problems about internet connection were found in Sri Lanka. Hayashi et al. (2020) [6] reported that the top obstacle faced by faculty and students during online learning was poor Internet access. During online teaching and learning, over 70 percent of students, 68 percent of faculty in state institutions, and 76 percent of non-state institutions experienced connection problems. Carey (2020) [12] also found that users can face several technical difficulties that impede and slow down the teachinglearning process.

Activities that the teachers conducted in the Online-class meeting

\begin{tabular}{|r|l|r|r|}
\hline No. & Teachers' activities in an online meeting & n & \% \\
\hline 1 & Review of the lesson presented in the pre-recorded video clips & 843 & $23 \%$ \\
\hline & $\begin{array}{l}\text { Responses to all students' questions that they had learned from } \\
\text { the LMS system }\end{array}$ & 1030 & $29 \%$ \\
\hline 3 & Help students do their exercises and homework & 686 & $19 \%$ \\
\hline 4 & Instructing students to do problem-solving or quizzes & 703 & $20 \%$ \\
\hline 5 & Giving lectures on some related content of the lesson & 339 & $9 \%$ \\
\hline & Total & 3601 & $100 \%$ \\
\hline
\end{tabular}

Table 3 presents the teaching activities that the lecturers conducted in their online meeting classes. As can be seen, the most common teaching activity that the lecturers employed for their online-meeting classes was for responses to the students' questions that they had learned from the LMS system $(n=1030 ; 29 \%)$. Since the students conducted their autonomous studies before the class-meetings, they could raise any questions to the lecturers to help them due to difficult problems or knowledge that they could not obtain. This was correspondent to the ZPD of Vygotsky's study [15]. The students could learn some knowledge by themselves; some other knowledge that they could not gain by themselves requires assistance from the older students or the lecturers. The second teaching activity that the students favored when studying with the onlinemeetings was that they requested the lecturers to review the lessons they broadcast via the prerecorded video clips $(n=843 ; 23 \%)$. They needed the lecturers to review the main points of the content to be sure of what they have already learned. The third favored teaching activity via the online-meeting classes was instructing students to do the problemsolving or quizzes $(n=703 ; 20 \%)$. Solving-problem activities were to create students' critical thinking to solve problems relating to the lessons' content, and doing quizzes at the end of the lessons/chapter was 
to help students consolidate or memorize what they had learned. Finally, helping students do the exercises or homework was the fourth favored activity for the students in the online-classes $(n=686$; $19 \%$ ). Doing exercises or homework referred to the activity that helped the students review the lesson's main content when they studied new knowledge. In Sri Lanka, Hayashi et al. (2020) found that nearly $90 \%$ of students were highly or moderately satisfied with online education.

In the qualitative data, the students revealed some difficulties of learning online-meeting. First, many students stated that it was so hard for the students to watch the long video clips for an hour or longer, (Học trên elearning để ôn bài và nộp bài thì rất tiện. Nhưng với bài mới em không thể coi clip giảng 1 tiếng mấy như coi phim được. Học offline không hiểu chỗ nào em hỏi liền được). Second, the

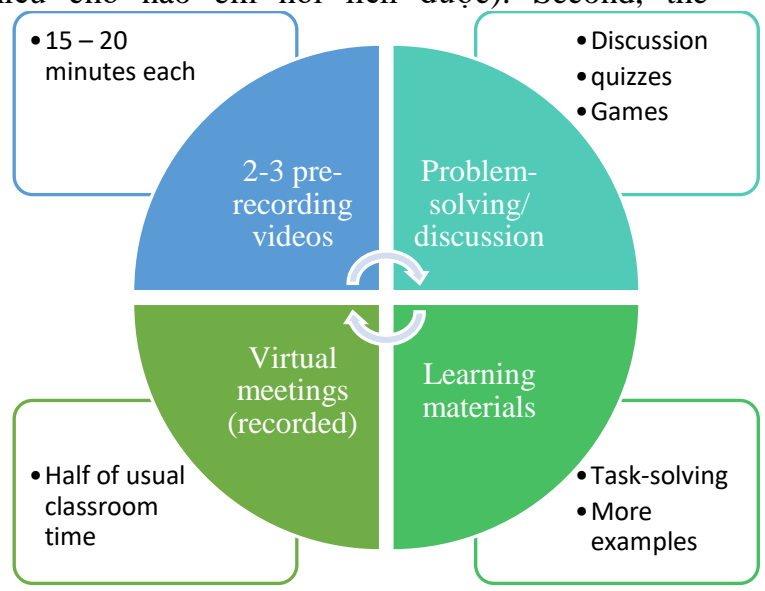

Fig. 7 Model for e-learning via LMS (Moodle).

\section{CONCLUSION}

E-learning is not just recording a video and providing materials on an LMS. It needs more active activities to support students to cover all the subjects' main areas. The lecturers should combine LMS (Moodle) and Online-meeting tools (MS TEAM) or other tools such as Zoom, Loom, Google Meet, etc., to conduct their e-learning effectively (figs. $7 \& 8$ ). First, each teaching lesson should contain from 2 to 3 pre-recorded video clips to present the lesson. The pre-recorded video clips were seen as the best learning resources as the students could learn any time and anywhere. They could review and pause at any section to master new knowledge or skills. However, each video clip should not be longer than 20 minutes to pay attention to their studies. Longer video clips were seen as difficult for the students' concentration. Second, problem-solving should be used to help students create critical thinking. A discussion session should be employed to activate students' schemata to easily learn new knowledge. Quizzes should be employed
Interactions were limitted when study online, and not easy to raise questions to the teachers (Tương tác trên TEAM cực kỳ hạn chế, chỉ 1 người on mic 1 lúc, ngoài ra còn tạp âm nữa, chưa kể đang học rớt mạng). Third, it was not easy for the students to submit assignments via smartphones.

Tất cả đều khó hiểu khi giảng qua màn hình và chỉ nghe được giọng nói của thầy cô, thay vì trên lớp chỗ nào không hiểu thì thầy cô còn giảng trực tiếp dễ hiểu hơn rất nhiều. Còn học online chỗ nào không hiểu thì cũng chỉ nghe được giọng nói chứ không hình dung ra được.

Therefore, the current study suggested a model for e-learning (LMS), as illustrated in fig. 7, and a model for the virtual meeting via MS TEAM in fig. 8 as follows:

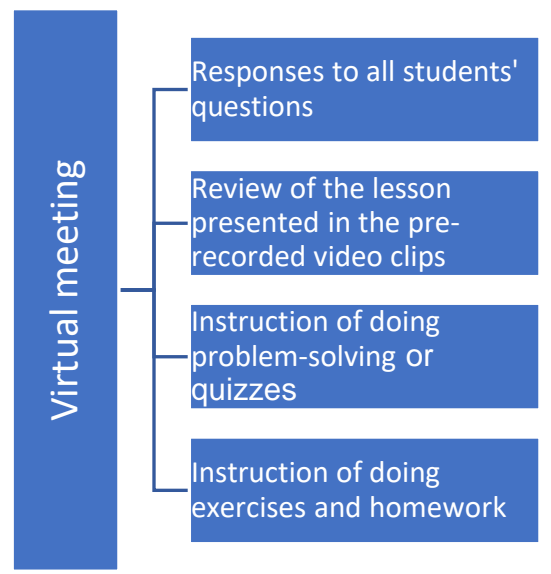

Fig. 8 Model for virtual meeting classes (Moodle).

to help students review the lessons' core content, and games were used to help students learn with fun. Third, learning materials such as book chapters, books, or related video-clip sessions be provided for the students to broaden their knowledge and gain new experience better. Finally, recorded-video of the online meeting classes should be embedded in the LMS to watch again and again to review the lessons. In case some students were missing the online-meeting courses, they could come back to the LMS to learn the lesson no matter what constraint of time.

In terms of online-meeting classes, the four most common activities that the lecturers could employ were (1) responses to all students' questions as they had learned the lessons via LMS before the onlinemeeting classes, (2) review of the lesson presented in the pre-recorded video clips, (3) instruction of doing problem-solving or quizzes, and (4) Instruction of doing exercises and homework.

The interactions between teachers and students are still limited in e-learning. Teachers can make use of other Apps such as Zalo (in Vietnam), Facebook 
Messenger, Kakao Talk (in Korea), Weibo (in China), Viber... to keep contact with their students.

E-learning is not as cheap as many people think. The time needed for online teaching was 14 percent longer than traditional teaching. The ideal class size for online courses should be $12-17$ students per class (Tomei, 2006) [16]. According to Cavenaugh (2005) [17], the effort needed to teach the online section for 15 students was equivalent to 40 students in the face-to-face area. It took six times as much effort as a face-to-face course to conduct an online course.

\section{REFERENCES}

[1] H.-H. Pham and T.-T.-H. Ho, "Toward a 'new normal' with e-learning in Vietnamese higher education during the post COVID-19 pandemic," Higher Education Research \& Development, vol. 39, no. 7, pp. 1327-1331, 2020.

[2] U. Jamal, "What does the rise of online learning during COVID-19 mean for Southeast Asia?," 1 Jan 2020. [Online]. Available: https://www.aseantoday.com/2020/08/whatdoes-the-rise-of-online-learning-during-covid19-mean-for-southeast-asia/. [Accessed 11 Jan 2021].

[3] S. Dharmaraj, "E-learning platforms in Vietnam grow amid COVID-19 breakout," 19 March 2020. [Online]. Available: https://opengovasia.com/e-learning-platformsin-vietnam-grow-amid-covid-19-breakout/. [Accessed 7 Jan 2021].

[4] D. Rahman, "A reckoning for online learning in times of crisis," 24 March 2020. [Online]. Available: https://www.thestar.com.my/opinion/columnist s/whats-your-status/2020/03/24/a-reckoningfor-online-learning-in-times-of-crisis. [Accessed 7 Jan 2021].

[5] N. Yarrow, "COVID-19 in East Asia: How the Region's Higher Education Systems are Addressing the Crisis to Adapt to the Future," 23 June 2020. [Online]. Available: https://blogs.worldbank.org/education/covid19-east-asia-how-regions-higher-educationsystems-are-addressing-crisis-adapt. [Accessed 6 Jan 2020].

[6] R. Hayashi, M. Garcia, A. Maddawin and K. P. Hewagamage, "Online Learning in Sri Lanka's Higher Education Institutions during the coVId-19 Pandemic," ADB BRIEFS NO. 151, pp. 1-12, September 2020.
[7] TheWorldBank, "Covid-19 Coronavirus Response," 2020. [Online]. Available: http://documents1.worldbank.org/curated/en/5 06241590701178057/COVID-19-Impact-onTertiary-Education-in-East-Asia-andPacific.pdf. [Accessed 7 Jan 2021].

[8] S. Dhawan, "Online Learning:A Panacea in the Timeof COVID-19 Crisis," Journal of Educational Technology Systems, vol. 49, no. 1, pp. 5-22, 2020.

[9] MOET, "The Information and Communications going along with Education and Training in the preventing Covid-19," 2 April 2020. [Online]. Available: https://en.moet.gov.vn/news/Pages/events.aspx ?ItemID=3933. [Accessed Jan 2021].

[10] MOE, "RESPONDINGTO COVID-19 :ONLINE CLASSESIN KOREA," Jun 2020. [Online]. Available: www.moe.go.kr.

[11] L. Ta, "East Asia Watch: Online learning in East Asia amid the coronavirus epidemic common challenges," 21 April 2020. [Online]. Available: https://educationservices.britishcouncil.org/insights-blog/eastasia-watch-online-learning-east-asia-amidcoronavirus-epidemic-\%E2\%80\%93-common. [Accessed 7 Jan 2021].

[12] K. Carey, "Everybody Ready for the Big Migration to Online College? Actually, No," 13 March 2020. [Online]. Available: https://www.nytimes.com/2020/03/13/upshot/c oronavirus-online-college-classesunprepared.html. [Accessed Jan 2021].

[13] C. Kalenzi, D. Back and M. Yim, "The future of online education: lessons from South Korea," 13 Nov. 2020. [Online]. Available: https://www.weforum.org/agenda/2020/11/less ons-from-south-korea-on-the-future-of-onlineeducation/. [Accessed 21 Jan 2021].

[14] C. Ho-him, "Coronavirus: Hong Kong students adapt to online learning amid class suspension over pandemic," 16 March 2020. [Online]. Available: https://www.scmp.com/news/hongkong/education/article/3075280/coronavirushong-kong-students-adapt-online-learningamid. [Accessed 18 Jan 2021].

[15] L. S. Vygotsky, Mind in society: The development of higher psychological processes, Boston: Harvard university press, 1980.

[16] L. Tomei, "The Impact of Online Teaching on Faculty Load: Computing the Ideal Class Size 
for Online Courses," Journal of Technology

and Teacher Education, vol. 14, no. 3, pp. 531541, 2006.

[17] J. Cavanaugh, "Teaching online-A time comparison," Online Journal of Distance
Learning Administration, vol. 8, no. 1, pp. 111, April 2005. 